\title{
Activity Coefficients of Potassium Chloride in Aqueous Solutions of Potassium Chloride and Potassium Phthalate
}

\author{
A. Marques, ${ }^{*}$ M.I.A. Ferra, M.H. Bandeira \\ Dep. Química, Univ. Beira-Interior, 6201-001 Covilhã, Portugal
}

Received 22 November 2005; accepted in revised form 11 April 2006

\begin{abstract}
Mean activity coefficients of potassium chloride were determined in aqueous solutions of potassium chloride and potassium phthalate, in the temperature range $10-50{ }^{\circ} \mathrm{C}$ and ionic strength range $0.05-4 \mathrm{~mol} \mathrm{~kg}^{-1}$, from potentiometric measurements on a galvanic cell without liquid junction. By processing the results using the Pitzer model, interaction parameters for potassium phthalate were calculated as well as their temperature dependence.
\end{abstract}

Keywords: activity coefficients, potassium phthalate, Pitzer equations.

\section{Introduction}

Sodium and potassium phthalate salts have a large application in industry and in chemical analysis. Particularly potassium hydrogen phthalate has been used as a standard substance and a $0.05 \mathrm{~mol} \mathrm{~kg}^{-1}$ aqueous solution of this salt was selected as a primary standard for $\mathrm{pH}$ determination [1]. According to the methodology for assigning $\mathrm{pH}$ values to the standards, the chloride ion activity coefficient has to be calculated by means of the Debye-Hückel equation with the BatesGuggenheim convention [1,2], valid for ionic strength not higher than $0.1 \mathrm{~mol}$ $\mathrm{kg}^{-1}$. For more concentrated solutions this equation does not fit most experimental data and the Pitzer theory [3] appears to be more adequate to describe the non ideal behaviour of most electrolytes [4,5]. The Pitzer approach separates arbitrarily between electrostatic and specific short-range interactions, and enables these, expressed as virial coefficients, to be calculated for single electrolyte solutions and applied to the analysis of mixtures [5].

\footnotetext{
* Corresponding author. E-mail address: ammmba@ubi.pt
} 
In potassium hydrogenphthalate $(\mathrm{KHPh})$ solutions, the three species, $\mathrm{H}_{2} \mathrm{Ph}, \mathrm{HPh}^{-}$ and $\mathrm{Ph}^{2-}$, are at equilibrium and the interactions between $\mathrm{Ph}^{2-}$ and $\mathrm{K}^{+}$are also important for the evaluation of the deviations from ideal behaviour.

In this work potassium chloride activity coefficients were determined in mixed solutions of potassium chloride and potassium phthalate (indicated by $\mathrm{K}_{2} \mathrm{Ph}$, for simplicity) from potentiometric measurements, in the temperature range 10 to 50 ${ }^{\circ} \mathrm{C}$.

The Pitzer equation for the calculation of potassium chloride activity coefficient was then fitted to the experimental data and the interaction coefficients, relative to potassium and phthalate ions, could be evaluated, at each temperature, by multilinear regression analysis.

\section{Experimental}

Mean activity coefficients of potassium chloride in $\mathrm{KCl}+\mathrm{K}_{2} \mathrm{Ph}+\mathrm{H}_{2} \mathrm{O}$ systems were determined in the $10-50{ }^{\circ} \mathrm{C}$ temperature range, from potential measurements in the following galvanic cell, without liquid junction,

$$
\mathrm{Ag}, \mathrm{AgCl}\left|\mathrm{KCl}\left(\mathrm{m}_{1}\right), \mathrm{K}_{2} \mathrm{Ph}\left(\mathrm{m}_{2}\right)\right| \mathrm{K}^{+} \text {glass electrode }
$$

where $\mathrm{m}_{1}$ and $\mathrm{m}_{2}$ are the molalities of potassium chloride and potassium phthalate, respectively. The ionic strength, I, varied from 0.05 to $4 \mathrm{~mol} \mathrm{~kg}$.

In cell (A), a commercial potassium responsive glass electrode, ABB KentTaylor, model 1057, and silver, silver chloride electrodes of the thermal electrolytic type [6], prepared in this laboratory, were used. The bias potentials of these electrodes were always lower than $0.1 \mathrm{mV}$. The cell response was tested by measuring the potential, on cell (A), E, at $25^{\circ} \mathrm{C}$, with $\mathrm{KCl}$ solutions, and using the equation

$$
\mathrm{E}=\mathrm{E}^{0}+2 \mathrm{~s} \ln \left(\mathrm{m}_{\mathrm{KCl}} \gamma_{\mathrm{KCl}}\right)
$$

where $\mathrm{E}^{0}$ is a constant and $\mathrm{s}$ is the nernstian slope. The activity coefficients, $\gamma_{\mathrm{KCl}}$, were calculated by the Pitzer equation with the known interaction coefficients [3] and the slope was $2 \mathrm{~s}=52.11 \mathrm{mV}\left(\mathrm{R}^{2}=1, \mathrm{n}=5\right)$, close to the theoretical value.

For the solution preparation, potassium chloride, Merck p.a., and potassium phthalate, Aldrich, $98 \%$, were dried at $110{ }^{\circ} \mathrm{C}$ for about 12 hours and cooled in a desiccator over blue gel. The solutions were prepared by weight, with buoyancy corrections, using deionized water with a specific conductivity of $0.1 \mu \mathrm{S} \mathrm{cm}^{-1}$. The $\mathrm{H}$ type cell vessels were immersed in a thermostated water bath (Grant, model LTD 20) and the temperature was controlled within $\pm 0.05^{\circ} \mathrm{C}$.

The potential differences of cell (A) were measured on a multimeter, Hewlett Packard, model HP 3458. 
Table 1. Solutions composition, potential for cell A and experimental $\mathrm{KCl}$ activity coefficients at various temperatures.

\begin{tabular}{|c|c|c|c|c|c|c|c|}
\hline \multirow{2}{*}{$\mathrm{m}_{\mathrm{KCl}}$} & \multirow[b]{2}{*}{$\mathrm{m}_{\mathrm{K} 2 \mathrm{Ph}}$} & \multicolumn{2}{|c|}{$10^{\circ} \mathrm{C}$} & \multicolumn{2}{|c|}{$20^{\circ} \mathrm{C}$} & \multicolumn{2}{|c|}{$25^{\circ} \mathrm{C}$} \\
\hline & & $\mathrm{E} / \mathrm{mV}$ & $-\ln \gamma_{\mathrm{KCl}}$ & $\mathrm{E} / \mathrm{mV}$ & $-\ln \gamma_{\mathrm{KCl}}$ & $\mathrm{E} / \mathrm{mV}$ & $-\ln \gamma_{\mathrm{KCl}}$ \\
\hline 0.0496 & & 15.70 & 0.20112 & 9.50 & 0.20330 & 7.58 & 0.20442 \\
\hline 0.03993 & 0.00336 & 9.31 & 0.18578 & 2.18 & 0.20112 & -0.41 & 0.20425 \\
\hline 0.02499 & 0.00833 & -5.03 & 0.18858 & -12.52 & 0.19957 & -15.56 & 0.21235 \\
\hline 0.01997 & 0.00999 & -11.34 & 0.18509 & -19.22 & 0.19854 & -22.57 & 0.21425 \\
\hline 0.09993 & & 48.55 & 0.26103 & 42.96 & 0.26326 & 40.38 & 0.26458 \\
\hline 0.07987 & 0.00679 & 41.63 & 0.25731 & 35.58 & 0.26935 & 33.02 & 0.37920 \\
\hline 0.05989 & 0.01359 & 32.20 & 0.27123 & 26.65 & 0.26589 & 23.57 & 0.38746 \\
\hline 0.04991 & 0.01698 & 27.79 & 0.25180 & 20.89 & 0.26944 & 17.82 & 0.39280 \\
\hline 0.03995 & 0.02039 & 21.70 & 0.24620 & 14.52 & 0.26450 & 11.03 & 0.26861 \\
\hline 0.29956 & & 97.54 & 0.37501 & 95.49 & 0.37609 & 91.9 & 0.37691 \\
\hline 0.17976 & 0.04077 & 82.85 & 0.35240 & 78.67 & 0.38362 & 75.15 & 0.27314 \\
\hline 0.14983 & 0.05096 & 77.19 & 0.35872 & 72.65 & 0.39249 & 69.09 & 0.27531 \\
\hline 0.11983 & 0.06113 & 70.85 & 0.35738 & 65.57 & 0.40062 & 62.07 & 0.27707 \\
\hline 0.49950 & & 121.59 & 0.43332 & 118.75 & 0.43280 & 117.31 & 0.43289 \\
\hline 0.39951 & 0.03398 & 114.92 & 0.42519 & 111.99 & 0.42109 & 110.01 & 0.43014 \\
\hline 0.24960 & 0.08489 & 101.26 & 0.41563 & 96.62 & 0.43427 & 94.31 & 0.44620 \\
\hline 0.19977 & 0.10193 & 94.52 & 0.42326 & 89.93 & 0.43552 & 87.37 & 0.45077 \\
\hline 0.09986 & 0.13590 & 75.84 & 0.41809 & 70.11 & 0.43784 & 67.40 & 0.45144 \\
\hline 0.99885 & & 152.67 & 0.51168 & 151.01 & 0.50536 & 149.90 & 0.50512 \\
\hline 0.49939 & 0.16986 & 133.94 & 0.46175 & 129.35 & 0.49812 & 127.36 & 0.51003 \\
\hline 0.39959 & 0.20387 & 126.81 & 0.47708 & 122.44 & 0.50341 & 120.24 & 0.51718 \\
\hline 0.19975 & 0.27180 & 107.83 & 0.47804 & 102.45 & 0.50906 & 100.25 & 0.51886 \\
\hline 1.49824 & & 169.56 & 0.55215 & 168.82 & 0.54357 & 168.04 & 0.53979 \\
\hline 0.74907 & 0.25470 & 150.25 & 0.51411 & 147.37 & 0.53220 & 145.49 & 0.54489 \\
\hline 0.59926 & 0.30576 & 142.30 & 0.54606 & 140.46 & 0.53731 & 138.57 & 0.54860 \\
\hline 0.29958 & 0.41523 & 124.76 & 0.52433 & 120.78 & 0.54368 & 118.36 & 0.56074 \\
\hline 1.99654 & & 184.36 & 0.57483 & 185.05 & 0.56263 & 182.99 & 0.55706 \\
\hline 1.59822 & 0.13590 & 177.99 & 0.56137 & 177.60 & 0.56533 & 175.58 & 0.55727 \\
\hline 1.19828 & 0.27172 & 169.50 & 0.5558 & 167.83 & 0.57817 & 165.72 & 0.56961 \\
\hline 0.99870 & 0.33970 & 164.03 & 0.55819 & 161.81 & 0.58701 & 159.91 & 0.57298 \\
\hline 0.39954 & 0.54360 & 138.83 & 0.55598 & 135.19 & 0.59258 & 132.93 & 0.57942 \\
\hline 2.99654 & & 201.74 & 0.59133 & 201.39 & 0.57272 & 202.36 & 0.56402 \\
\hline 1.79778 & 0.40766 & 187.80 & 0.55307 & 185.77 & 0.55638 & 185.36 & 0.57093 \\
\hline 1.49799 & 0.50952 & 182.79 & 0.54579 & 179.67 & 0.56655 & 179.38 & 0.57736 \\
\hline 1.19861 & 0.61156 & 176.19 & 0.55026 & 173.24 & 0.56238 & 172.42 & 0.58203 \\
\hline 0.59917 & 0.81524 & 157.17 & 0.55201 & 153.18 & 0.56938 & 152.04 & 0.59064 \\
\hline 3.99511 & & 214.87 & 0.58526 & 217.02 & 0.56154 & 216.53 & 0.55033 \\
\hline 2.39689 & 0.54353 & 199.97 & 0.56669 & 201.42 & 0.54482 & 200.97 & 0.52924 \\
\hline 1.99729 & 0.67937 & 194.94 & 0.55987 & 195.71 & 0.54736 & 194.88 & 0.53786 \\
\hline 1.59757 & 0.81508 & 188.76 & 0.55536 & 188.71 & 0.55405 & 187.65 & 0.54741 \\
\hline 0.79868 & 1.08666 & 169.19 & 0.56848 & 168.41 & 0.56587 & 167.44 & 0.55280 \\
\hline
\end{tabular}


Table 1. Solutions composition, potential values for cell $\mathrm{A}$ and experimental $\mathrm{KCl}$ activity coefficients at various temperatures (cont.).

\begin{tabular}{|c|c|c|c|c|c|c|c|}
\hline \multirow{2}{*}{$\mathrm{m}_{\mathrm{KCl}}$} & \multirow{2}{*}{$\mathrm{m}_{\mathrm{K} 2 \mathrm{Ph}}$} & \multicolumn{2}{|c|}{$30^{\circ} \mathrm{C}$} & \multicolumn{2}{|c|}{$40^{\circ} \mathrm{C}$} & \multicolumn{2}{|c|}{$50^{\circ} \mathrm{C}$} \\
\hline & & $\mathrm{E} / \mathrm{mV}$ & $-\ln \gamma_{\mathrm{KCl}}$ & $\mathrm{E} / \mathrm{mV}$ & $-\ln \gamma_{\mathrm{KCl}}$ & $\mathrm{E} / \mathrm{mV}$ & $-\ln \gamma_{\mathrm{KCl}}$ \\
\hline 0.0496 & & 4.48 & 0.20582 & -1.20 & 0.20874 & -6.17 & 0.21199 \\
\hline 0.03993 & 0.00336 & -3.62 & 0.21453 & -9.68 & 0.21954 & -14.78 & 0.22027 \\
\hline 0.02499 & 0.00833 & -19.20 & 0.22171 & -25.75 & 0.22628 & -31.26 & 0.22516 \\
\hline 0.01997 & 0.00999 & -26.22 & 0.22312 & -33.09 & 0.22932 & -38.71 & 0.22597 \\
\hline 0.09993 & & 38.27 & 0.26595 & 32.97 & 0.26992 & 28.81 & 0.27288 \\
\hline 0.07987 & 0.00679 & 30.27 & 0.27985 & 24.85 & 0.28042 & 20.32 & 0.28609 \\
\hline 0.05989 & 0.01359 & 20.62 & 0.28524 & 14.83 & 0.28677 & 10.21 & 0.28832 \\
\hline 0.04991 & 0.01698 & 14.60 & 0.29060 & 8.89 & 0.28697 & 4.15 & 0.28726 \\
\hline 0.03995 & 0.02039 & 7.59 & 0.29439 & 1.63 & 0.29111 & -3.27 & 0.29011 \\
\hline 0.29956 & & 90.87 & 0.37785 & 87.64 & 0.38046 & 84.71 & 0.38375 \\
\hline 0.17976 & 0.04077 & 73.60 & 0.38473 & 69.44 & 0.39401 & 66.29 & 0.39082 \\
\hline 0.14983 & 0.05096 & 67.31 & 0.39544 & 63.14 & 0.40106 & 59.99 & 0.39426 \\
\hline 0.11983 & 0.06113 & 60.09 & 0.40235 & 55.95 & 0.40300 & 52.63 & 0.39514 \\
\hline 0.49950 & & 117.02 & 0.43311 & 114.56 & 0.43440 & 112.33 & 0.43654 \\
\hline 0.39951 & 0.03398 & 108.91 & 0.44351 & 105.61 & 0.45542 & 103.36 & 0.45278 \\
\hline 0.24960 & 0.08489 & 93.00 & 0.45856 & 89.72 & 0.46037 & 87.06 & 0.45598 \\
\hline 0.19977 & 0.10193 & 85.96 & 0.46281 & 82.48 & 0.46403 & 79.86 & 0.45477 \\
\hline 0.09986 & 0.13590 & 65.38 & 0.46875 & 61.55 & 0.46387 & 58.20 & 0.45572 \\
\hline 0.99885 & & 150.36 & 0.50342 & 149.10 & 0.50106 & 148.06 & 0.49977 \\
\hline 0.49939 & 0.16986 & 126.01 & 0.53573 & 123.89 & 0.53442 & 122.69 & 0.52156 \\
\hline 0.39959 & 0.20387 & 118.83 & 0.54238 & 116.71 & 0.53668 & 115.46 & 0.52059 \\
\hline 0.19975 & 0.27180 & 98.56 & 0.54237 & 95.77 & 0.53670 & 94.09 & 0.51633 \\
\hline 1.49824 & & 169.44 & 0.53618 & 169.24 & 0.53021 & 168.96 & 0.52543 \\
\hline 0.74907 & 0.25470 & 144.69 & 0.57615 & 143.68 & 0.57006 & 143.46 & 0.54955 \\
\hline 0.59926 & 0.30576 & 137.77 & 0.57764 & 136.50 & 0.57214 & 136.14 & 0.55003 \\
\hline 0.29958 & 0.41523 & 117.68 & 0.58100 & 115.67 & 0.57694 & 114.68 & 0.55419 \\
\hline 1.99654 & & 184.22 & 0.55168 & 185.20 & 0.54230 & 185.01 & 0.53421 \\
\hline 1.59822 & 0.13590 & 175.78 & 0.56923 & 175.28 & 0.58211 & 175.78 & 0.55595 \\
\hline 1.19828 & 0.27172 & 165.94 & 0.57802 & 165.20 & 0.58934 & 165.78 & 0.55596 \\
\hline 0.99870 & 0.33970 & 160.21 & 0.57799 & 159.47 & 0.58580 & 159.99 & 0.55022 \\
\hline 0.39954 & 0.54360 & 133.08 & 0.57845 & 131.13 & 0.59230 & 143.64 & 0.32516 \\
\hline 2.99654 & & 204.52 & 0.55551 & 206.90 & 0.54007 & 206.90 & 0.52608 \\
\hline 1.79778 & 0.40766 & 185.48 & 0.59602 & 185.98 & 0.60377 & 187.70 & 0.54690 \\
\hline 1.49799 & 0.50952 & 179.56 & 0.59938 & 179.82 & 0.60796 & 181.43 & 0.54954 \\
\hline 1.19861 & 0.61156 & 172.66 & 0.60066 & 173.16 & 0.60058 & 174.38 & 0.54534 \\
\hline 0.59917 & 0.81524 & 152.17 & 0.60483 & 151.71 & 0.61002 & 152.79 & 0.54499 \\
\hline 3.99511 & & 218.12 & 0.53928 & 221.33 & 0.51899 & 222.80 & 0.50026 \\
\hline 2.39689 & 0.54353 & 201.00 & 0.54305 & 201.57 & 0.56122 & 203.47 & 0.52344 \\
\hline 1.99729 & 0.67937 & 194.94 & 0.54914 & 195.56 & 0.56268 & 197.25 & 0.52523 \\
\hline 1.59757 & 0.81508 & 187.61 & 0.55829 & 188.20 & 0.56790 & 189.83 & 0.52731 \\
\hline 0.79868 & 1.08666 & 166.90 & 0.56676 & 166.72 & 0.57799 & 167.90 & 0.53316 \\
\hline
\end{tabular}

\section{Results and discussion}

Solutions composition is given in table 1 along with the potential difference of cell (A), E, and mean activity coefficients of potassium chloride. For each series of measurements, the ionic strength was kept constant. Mean activity coefficients for $\mathrm{KCl}$ in the system $\mathrm{KCl}+\mathrm{K}_{2} \mathrm{Ph}+\mathrm{H}_{2} \mathrm{O}, \gamma_{\mathrm{KCl}}$, were calculated from emf data, using the rearranged form of the Nernst equation

$$
\ln \left(\gamma_{\mathrm{KCl}}\right)=\Delta \mathrm{E} / 2 \mathrm{~s}-1 / 2 \ln \left[\left(\mathrm{m}_{1}+2 \mathrm{~m}_{2}\right) \mathrm{m}_{1}\right]+\ln \left(\mathrm{m}_{\mathrm{KCl}}^{0}\right)+\ln \left(\gamma_{\mathrm{KCl}}^{0}\right)
$$


where $\Delta \mathrm{E}$ is the difference between two measurements on cell (A), with and without $\mathrm{K}_{2} \mathrm{Ph}, \mathrm{m}_{1}$ and $\mathrm{m}_{2}$ are the molalities of $\mathrm{KCl}$ and $\mathrm{K}_{2} \mathrm{Ph}$, respectively, $\mathrm{m}_{\mathrm{KCl}}^{0}$ is the molality of $\mathrm{KCl}$ in the solutions without $\mathrm{K}_{2} \mathrm{Ph}$ and $\gamma_{\mathrm{KCl}}^{0}$ is the activity coefficient of $\mathrm{KCl}$ calculated by the Pitzer equation with the ionic interaction coefficients given in Table 2. These values were obtained from data at $25^{\circ} \mathrm{C}$ and the respective temperature derivative [5]. The cell potentials, without $\mathrm{K}_{2} \mathrm{Ph}$, were also used to evaluate the s value, in equation (1), at each temperature, which is compared with the theoretical value [7] in Table 3.

Table 2. Pitzer parameters for potassium chloride [5].

\begin{tabular}{llll}
\hline $\mathrm{t} /{ }^{\circ} \mathrm{C}$ & $\begin{array}{l}\beta^{(0)} / \\
\mathrm{mol}^{-1}\end{array}$ & $\begin{array}{l}\beta^{(1) /} \\
\mathrm{mol}^{-1}\end{array}$ & $\begin{array}{l}\mathrm{Cg} / \\
\mathrm{mol}^{-2}\end{array}$ \\
\hline 10 & 0.03966 & 0.19614 & -0.00004 \\
20 & 0.04545 & 0.20685 & -0.00029 \\
25 & 0.04835 & 0.21220 & -0.00042 \\
30 & 0.05125 & 0.21756 & -0.00055 \\
40 & 0.05704 & 0.22827 & -0.00080 \\
50 & 0.06284 & 0.23898 & -0.00106 \\
\hline
\end{tabular}

Due to the low hydrolysis constants for phthalate ion, the hydrogen phthalate ion and hydroxide ion molalities are very small, compared to that of phthalate ion, and they were neglected in the following calculations.

Table 3. Slope values for cell A (equation 1).

\begin{tabular}{ccc}
\hline $\mathrm{t} /{ }^{\circ} \mathrm{C}$ & $\mathrm{s} / \mathrm{mV}$ & $\mathrm{s}_{\mathrm{th}}{ }^{\mathrm{a}} / \mathrm{mV}$ \\
\hline 10 & 25.05 & 24.40 \\
20 & 25.84 & 25.26 \\
25 & 26.06 & 25.70 \\
30 & 26.64 & 26.12 \\
40 & 27.60 & 26.98 \\
50 & 28.20 & 27.85 \\
\hline${ }^{\mathrm{a}}{ }{ }_{\text {th }}$ Theoretical values [7] &
\end{tabular}

According to the Pitzer formalism [3], mean activity coefficients of $\mathrm{KCl}$ in the $\mathrm{KCl}+\mathrm{K}_{2} \mathrm{Ph}+\mathrm{H}_{2} \mathrm{O}$ system are given by

$$
\begin{aligned}
\ln \gamma_{K C l} & =F_{1}+\left(m_{K}+m_{C l}\right)\left(\beta_{K, C l}^{(0)}+\beta_{K, C l}^{(1)} F_{2}+m_{K} C_{K, C l}\right)+ \\
& +m_{P h} \theta_{C l P h}+\left(m_{K} m_{C l}\right)\left(\beta_{K, C l}^{(1)} F_{3}+C_{K, C l}\right)+ \\
& +1 / 2\left(m_{K} m_{P h}+m_{C l} m_{P h}\right) \psi_{K, C l, P h}+ \\
& +m_{P h}\left(\beta_{K, P h}^{(0)}+\beta_{K, P h}^{(1)} F_{2}+m_{K} C_{k, P h}\right)+ \\
& +\left(m_{K} m_{P h}\right)\left(\beta_{K, P h}^{(1)} F_{3}+C_{K, P h}\right) \\
& +m_{C l} m_{P h} \theta_{C l, P h}^{\prime}
\end{aligned}
$$


where $F_{1}, F_{2}$ and $F_{3}$ are functions of the ionic strength, I,

$$
\begin{gathered}
F_{1}=-A_{\phi}\left[\frac{\sqrt{I}}{1+1.2 \sqrt{I}}+\frac{2}{1.2} \ln (1+1.2 \sqrt{I})\right] \\
F_{2}=\frac{1}{2 I}[1-(1+2 \sqrt{I}) \exp (-2 \sqrt{I})] \\
F_{3}=\frac{1}{2 I^{2}}[-1+(1+2 \sqrt{I}+2 I) \exp (-2 \sqrt{I})]
\end{gathered}
$$

$\mathrm{m}$ is the molality of the species indicated in subscript, $\beta^{(0)}, \beta^{(1)}$ and $\mathrm{C}$ are interaction coefficients of the indicated salts, $\theta$ and $\psi$ are the second and third virial coefficients, respectively, for the mixed electrolyte, and $\theta^{\prime}$ is the $\theta$ derivative with respect to ionic strength [5].

The interaction of like charged ions, $\theta_{\mathrm{Cl}, \mathrm{Ph}}$, includes the effect of short range forces, ${ }^{\mathrm{s}} \theta_{\mathrm{Cl}, \mathrm{Ph}}$, and electrostatic effects of higher order, ${ }^{\mathrm{E}} \boldsymbol{\theta}_{\mathrm{Cl}, \mathrm{Ph}}$, and cannot always be neglected for unsymmetrical electrolyte mixtures. They are given by

$$
\theta_{\mathrm{Cl}, \mathrm{Ph}}={ }^{\mathrm{s}} \theta_{\mathrm{Cl}, \mathrm{Ph}}+{ }^{\mathrm{E}} \theta_{\mathrm{Cl}, \mathrm{Ph}}
$$

and

$$
\theta^{\prime}{ }_{\mathrm{Cl}, \mathrm{Ph}}={ }^{\mathrm{E}} \boldsymbol{\theta}^{\prime} \mathrm{Cl,Ph}
$$

For this work, ${ }^{\mathrm{E}} \boldsymbol{\theta} \mathrm{Cl,Ph}$ and ${ }^{\mathrm{E}} \boldsymbol{\theta}_{\mathrm{Cl}, \mathrm{Ph}}$ were calculated, at each temperature, following the procedure described by Pitzer [5]. The $\mathrm{K}_{2} \mathrm{Ph}$ interaction parameters could be obtained from multilinear regression on the equation

$$
\mathrm{Y}=\mathrm{m}_{\mathrm{Ph}}\left(\beta^{(0)}{ }_{\mathrm{K}, \mathrm{Ph}}+{ }^{\mathrm{s}} \theta_{\mathrm{Cl}, \mathrm{Ph}}\right)+\mathrm{m}_{\mathrm{Ph}}\left(\mathrm{F}_{2}+\mathrm{m}_{\mathrm{K}} \mathrm{F}_{3}\right) \beta^{(1)}{ }_{\mathrm{K}, \mathrm{Ph}}+2\left(\mathrm{~m}_{\mathrm{K}}+\mathrm{m}_{\mathrm{Ph}}\right) \mathrm{C}_{\mathrm{K}, \mathrm{Ph}}
$$

where $\mathrm{Y}$ includes the experimental $\ln \gamma_{\mathrm{KCl}}$, the items that correspond to specific interactions relative to $\mathrm{KCl}$ and ${ }^{\mathrm{E}} \boldsymbol{\theta}_{\mathrm{Cl}, \mathrm{Ph}}$ and ${ }^{\mathrm{E}} \boldsymbol{\theta}{ }_{\mathrm{Cl}, \mathrm{Ph}}$, according to equation (3). For most electrolytes, the mixing parameter, $\psi$, is close to zero [5] and was discarded in the present calculation. As shown by equation (9) it is not possible to determine $\beta^{(0)}{ }_{\mathrm{K}, \mathrm{Ph}}$ and ${ }^{\mathrm{s}} \theta_{\mathrm{Cl}, \mathrm{Ph}}$ separately. Nevertheless ${ }^{\mathrm{s}} \theta_{\mathrm{Cl}, \mathrm{Ph}}$ is expected to be much smaller than $\beta^{(0)}{ }_{\mathrm{K}, \mathrm{Ph}}$, from comparison to other electrolytes of the same kind; so we believe this is a good approximation for $\beta^{(0)} \mathrm{K}, \mathrm{Ph}$. The results are presented in Table 4 . Their temperature dependence can be expressed by

$$
\begin{gathered}
\beta^{(0)}{ }_{\mathrm{K}, \mathrm{Ph}}+{ }^{\mathrm{s}} \theta_{\mathrm{Cl}, \mathrm{Ph}}=1.59 \mathrm{E}-01+6 \mathrm{E}-04\left(\mathrm{~T}-\mathrm{T}_{\mathrm{r}}\right)+2.02 \mathrm{E}-04\left(\mathrm{~T}-\mathrm{T}_{\mathrm{r}}\right)^{2} \\
\beta^{(1)}{ }_{\mathrm{K}, \mathrm{Ph}}=1.46-4.8 \mathrm{E}-02\left(\mathrm{~T}-\mathrm{T}_{\mathrm{r}}\right)+1.39 \mathrm{E}-03\left(\mathrm{~T}-\mathrm{T}_{\mathrm{r}}\right)^{2} \\
\mathrm{C}_{\mathrm{K}, \mathrm{Ph}}=8.2 \mathrm{E}-03-2 \mathrm{E}-05\left(\mathrm{~T}-\mathrm{T}_{\mathrm{r}}\right)-3.0 \mathrm{E}-05\left(\mathrm{~T}-\mathrm{T}_{\mathrm{r}}\right)^{2}
\end{gathered}
$$


where $T$ is the absolute temperature and $T_{r}=298.15 \mathrm{~K}$ is the reference temperature.

Table 4. Pitzer interaction parameters for $\mathrm{K}_{2} \mathrm{Ph}$ including higher order electrostatic interactions.

\begin{tabular}{ccccc}
\hline $\mathrm{t} /{ }^{\circ} \mathrm{C}$ & $\beta^{(0)}+{ }^{\mathrm{s}} \theta / \mathrm{kg} \mathrm{mol}^{-1}$ & $\beta^{(1)} / \mathrm{kg} \mathrm{mol}^{-1}$ & $\mathrm{C} / \mathrm{kg}^{2} \mathrm{~mol}^{-2}$ & $\sigma^{\mathrm{a}}$ \\
\hline 10 & $0.181(0.059)$ & $2.54(0.32)$ & $0.0024(0.0081)$ & 0.0132 \\
20 & $0.181(0.047)$ & $1.68(0.26)$ & $0.0056(0.0064)$ & 0.0106 \\
25 & $0.161(0.022)$ & $1.48(0.12)$ & $0.0098(0.0031)$ & 0.0050 \\
30 & $0.189(0.048)$ & $1.00(0.26)$ & $0.0052(0.0065)$ & 0.0107 \\
40 & $0.162(0.060)$ & $1.39(0.33)$ & $0.0039(0.0082)$ & 0.0136 \\
50 & $0.323(0.035)$ & $0.99(0.19)$ & $-0.0123(0.0048)$ & 0.0079 \\
\hline${ }^{a}$ Residual standard deviation of regression. Standard errors are shown in brackets.
\end{tabular}

From a statistical point of view, $\mathrm{C}$ is zero at most temperatures studied. Even so, its values show a regular variation with temperature. The difference between $\mathrm{ln}$ $\gamma_{\mathrm{KCl}}(\exp )$, calculated by equation (2), and $\ln \gamma_{\mathrm{KCl}}$ (calc), obtained by equation (3), with the parameters presented in Table 4, was calculated for each solution. Fig. 1 shows these differences for these ionic strengths and temperatures.

The calculations were repeated without the higher order electrostatic terms and the results are given in Table 5. Both equations fit the experimental data identically and both sets of parameters are of the same order of magnitude. So, in these ionic strength and temperature ranges, the inclusion of the higher order electrostatic effects does not seem to improve the fit significantly. The $\mathrm{K}_{2} \mathrm{Ph}$ parameters were also redetermined including the mixing parameter, $\psi_{\mathrm{K}, \mathrm{Cl}, \mathrm{Ph}}$, with ${ }^{\mathrm{E}} \boldsymbol{\theta}_{\mathrm{Cl}, \mathrm{Ph}}$ and ${ }^{\mathrm{E}} \boldsymbol{\theta}^{\prime}{ }_{\mathrm{Cl}, \mathrm{Ph}}$ in equation (3) and no better fit was found.

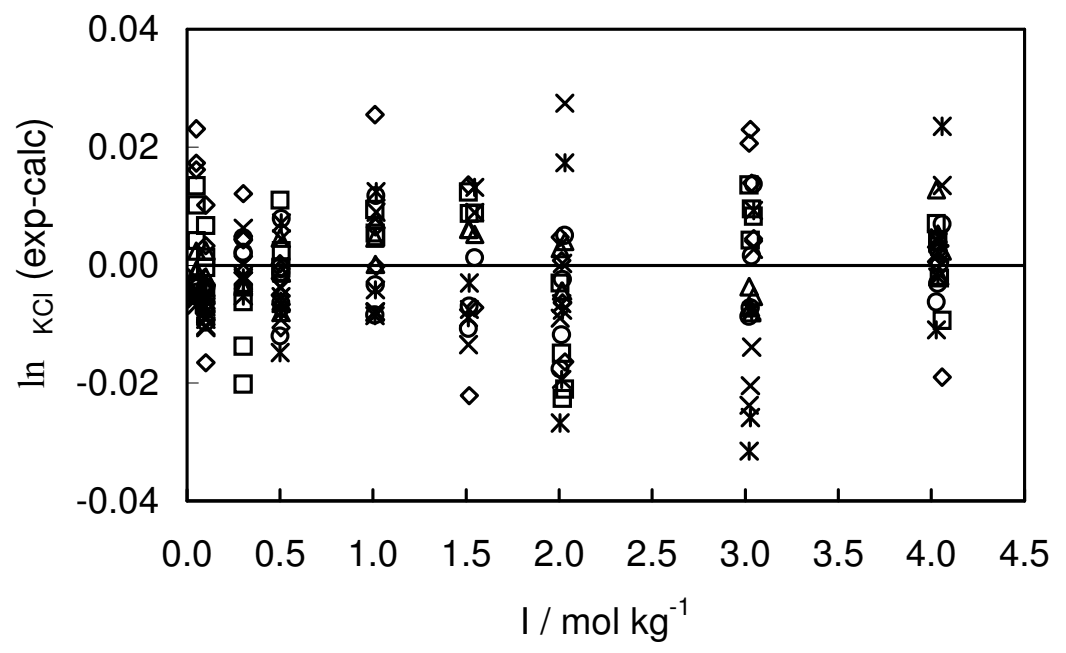

Figure 1. Difference between experimental (equation 2) and calculated (equation 3) In $\gamma_{\mathrm{KCl}}$ in aqueous $\mathrm{KCl}+\mathrm{K}_{2} \mathrm{Ph}$ solutions: $\diamond 10^{\circ} \mathrm{C} ; \square 20^{\circ} \mathrm{C} ; \Delta 25^{\circ} \mathrm{C} ; \times 30^{\circ} \mathrm{C}$; $* 40{ }^{\circ} \mathrm{C}$; o $50{ }^{\circ} \mathrm{C}$. 
Table 5. Pitzer interaction parameters for $\mathrm{K}_{2} \mathrm{Ph}$ without higher order electrostatic interactions.

\begin{tabular}{lcccc}
\hline $\mathrm{t} /{ }^{\circ} \mathrm{C}$ & $\beta^{(0)}+\theta / \mathrm{kg} \mathrm{mol}^{-1}$ & $\beta^{(1)} / \mathrm{kg} \mathrm{mol}^{-1}$ & $\mathrm{C} / \mathrm{kg}^{2} \mathrm{~mol}^{-2}$ & $\sigma^{\mathrm{a}}$ \\
\hline 10 & $0.120(0.062)$ & $2.16(0.34)$ & $0.0053(0.0084)$ & 0.0139 \\
20 & $0.119(0.048)$ & $1.30(0.26)$ & $0.0085(0.0066)$ & 0.0109 \\
25 & $0.099(0.025)$ & $1.09(0.14)$ & $0.0128(0.0034)$ & 0.0056 \\
30 & $0.127(0.044)$ & $0.61(0.24)$ & $0.0082(0.0060)$ & 0.0099 \\
40 & $0.099(0.054)$ & $1.00(0.29)$ & $0.0067(0.0073)$ & 0.0121 \\
50 & $0.265(0.030)$ & $0.56(0.16)$ & $-0.0103(0.0042)$ & 0.0068 \\
\hline \multicolumn{4}{c}{${ }^{\mathrm{a}}$ Residual standard deviation of regression. Standard errors are shown in brackets. }
\end{tabular}

The values $\beta^{(0)}{ }_{\mathrm{K}, \mathrm{Ph}}=0.12 \mathrm{~mol}^{-1} \mathrm{~kg}$ and $\beta^{(1)}{ }_{\mathrm{K}, \mathrm{Ph}}=0.7 \mathrm{~mol}^{-1} \mathrm{~kg}$, reported by Chan and collaborators [8], were obtained, at $25^{\circ} \mathrm{C}$, from measurements on a Harned cell, where the electrolytes were potassium hydrogen phthalate and potassium chloride, with ionic strength ranging from 0.02 to $2 \mathrm{~mol} \mathrm{~kg}^{-1}$. Partanen and Minkkinen [9] used extensive Harned cell data of Hamer, Pinching and Acree [10] and Hamer and Acree [11] to determine the same parameters, $\beta^{(0)}{ }_{\mathrm{K}, \mathrm{Ph}}=0.31$ $\mathrm{mol}^{-1} \mathrm{~kg}$ and $\beta_{\mathrm{K}, \mathrm{Ph}}^{(1)}=0.70 \mathrm{~mol}^{-1} \mathrm{~kg}$. The ionic strength of those solutions was lower than $0.5 \mathrm{~mol} \mathrm{~kg} \mathrm{~kg}^{-1}$, as they were prepared for the determination of the ionization constants of phthalic acid by extrapolation to zero ionic strength.

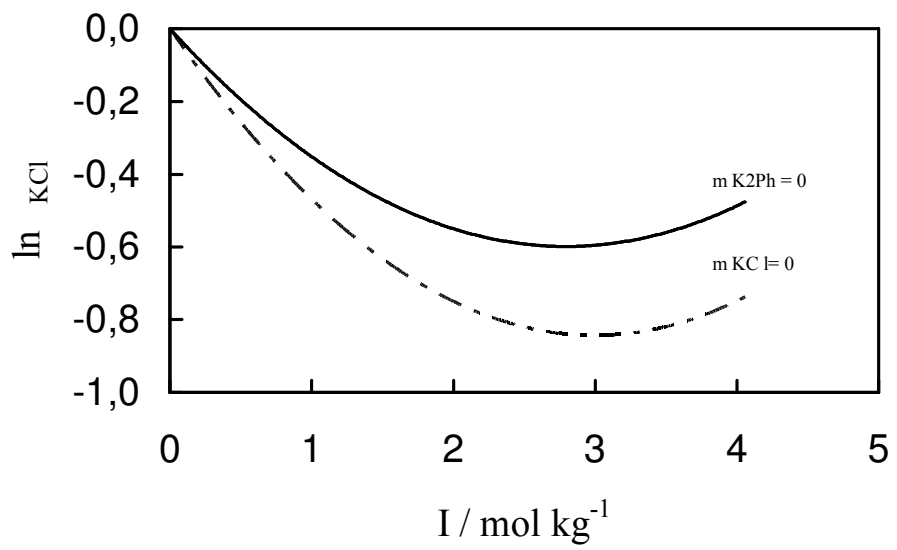

Figure 2. Calculated potassium chloride activity coefficient by equation (3): - single $\mathrm{KCl}\left(\mathrm{m}_{\mathrm{K} 2 \mathrm{Ph}}=0\right)$--- single $\mathrm{K}_{2} \mathrm{Ph}\left(\mathrm{m}_{\mathrm{KCl}}=0\right)$.

Mendonça and Jussola also determined activity coefficients of $\mathrm{KCl}$ in aqueous solutions of $\mathrm{KCl}$ and $\mathrm{K}_{2} \mathrm{Ph}$ using potentiometric data from a cell like the one indicated in the present work. Their Pitzer parameters, at $25^{\circ} \mathrm{C}$, are $\beta^{(0)}{ }_{\mathrm{K}, \mathrm{Ph}}+{ }^{\mathrm{s}} \theta_{\mathrm{Cl}, \mathrm{Ph}}$ $=0.25 \pm 0.01 \mathrm{~mol}^{-1} \mathrm{~kg}, \beta_{\mathrm{K}, \mathrm{Ph}}^{(1)}=0.86 \pm 0.08 \mathrm{~mol}^{-1} \mathrm{~kg}, \mathrm{C}_{\mathrm{K}, \mathrm{Ph}}=-0.10 \pm 0.002 \mathrm{~mol}^{-2}$ $\mathrm{kg}^{-2}$ and $\psi_{\mathrm{K}, \mathrm{Cl}, \mathrm{Ph}}=0.014 \pm 0.005 \mathrm{~mol}^{-2} \mathrm{~kg}^{-2}$ [12], with ionic strength varying from 0.6 to $4.5 \mathrm{~mol} \mathrm{~kg}^{-1}$. The values determined in the present work, given in Table 4, refer to a wider ionic strength range and show a regular variation with temperature. 
The variation of $\ln \gamma_{\mathrm{KCl}}$ with ionic strength is illustrated in Fig. 2 for the mixed electrolyte. The activity coefficient was calculated by equation (3), with the parameters given in Table 4 , at $25^{\circ} \mathrm{C}$. The two lines represent the limit situations where only $\mathrm{KCl}\left(\mathrm{m}_{\mathrm{K} 2 \mathrm{Ph}}=0\right)$ is present or only $\mathrm{K}_{2} \mathrm{Ph}\left(\mathrm{m}_{\mathrm{KCl}}=0\right)$.

\section{Conclusions}

Mean activity coefficients of $\mathrm{KCl}$ were determinated in the system $\mathrm{KCl}+\mathrm{K}_{2} \mathrm{Ph}+$ $\mathrm{H}_{2} \mathrm{O}$, in the temperature range $10-50{ }^{\circ} \mathrm{C}$, from potentiometric measurements in a galvanic cell without liquid junction. The ionic strength varied between 0.05 and $4 \mathrm{~mol} \mathrm{~kg}^{-1}$. The results were processed using the Pitzer theory. The interaction parameters obtained for potassium phthalate enable the calculation of mean activity coefficients of this salt in water or in aqueous solutions of potassium chloride, in those ionic strength and temperature ranges.

The results indicate that the inclusion of the higher order electrostatic terms in the Pitzer equation improves only slightly its fit to the experimental data. On another hand, if they are included, the new parameters are closer to those of other organic electrolytes of the same type [5]. As there is no phthalate ion selective electrode available, the potentiometric data were obtained from mixtures of two electrolytes with a common ion, $\mathrm{K}^{+}$. However, the Pitzer formalism enabled the use of the known parameters of one electrolyte in order to evaluate those relative to the other.

\section{References}

1. R.P. Buck, S. Rondinini, A.K. Covington, F.G.K. Baucke, C.M.A. Brett, M.F. Camões, M.J.T. Milton, T. Mussini, R. Naumann, K.W. Pratt, P. Spitzer, G.S. Wilson, Pure Appl. Chem. 74, 11 (2002) 2169-2200.

2. R.G. Bates, E.A. Guggenheim, Pure Appl. Chem. 1 (1960) 163.

3. K.S. Pitzer, J. Phys. Chem. 77 (1973) 268.

4. A.K. Covington, M.I.A. Ferra, J. Sol. Chem. 23 (1994) 1.

5. K.S. Pitzer, "Ion Interaction Approach: Theory and Data Correlation", in Activity Coefficients in Electrolyte Solutions, $2^{\text {nd }}$ ed., K.S. Pitzer, Ed., CRC Press, Boca Raton, Florida, U. S. A. 1991.

6. R.G. Bates, Determination of $p H$. Theory and Pratctice, $2^{\text {nd }}$ ed., John Wiley \& Sons, Inc., New York, U. S. A., 1973.

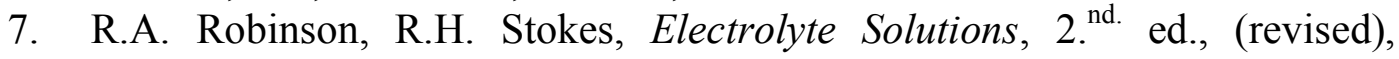
Butterworth \& Co, London, 1970.

8. C.Y. Chan, Y.W. Eng, K.S. Eu, J. Chem. Eng. Data 40 (1995) 685.

9. J.I. Partanen, P.O. Minkkinen, J. Chem. Eng. Data 42 (1997) 805.

10. W.J. Hamer, G.D. Pinching, S.F. Acree, J. Res. Natl. Bur. Stand. 35 (1945) 539.

11. W.J. Hamer, S.F. Acree, J. Res. Natl. Bur. Stand. 35 (1945) 381.

12. A.J.G. Mendonça, P.M. Juusola, Fluid Phase Equilibria 231 (2005) 114. 